\title{
ANALISIS INVESTASI BEBERAPA TINGKAT PADAT TEBAR BERONANG LADA (Siganus guttatus) PADA POLIKULTUR DENGAN UDANG WINDU (Penaeus monodon)
}

\author{
Haseng Padda*) dan Muhammad Tjaronge*)
}

\begin{abstract}
ABSTRAK
Polikultur udang windu dan beronang merupakan salah satu di antara sekian banyak cara untuk meningkatkan produksi, produktivitas dan pendapatan petambak. Penelitian bertujuan mengetahui investasi yang menguntungkan dari polikultur udang windu dan beronang pada beberapa kepadatan tebar. Penelitian menggunakan rancangan acak lengkap dengan empat perlakuan dan tiga ulangan. Kepadatan tebar perlakuan A adalah benur $40.000 \mathrm{ekor} / \mathrm{ha} / \mathrm{musim}$ tanam tanpa beronang, perlakuan B, C dan D adalah benur 40.000 ekor + benih beronang masing-masing 2.000, $4.000 \mathrm{dan} 6.000 \mathrm{ekor} / \mathrm{ha} / \mathrm{musim}$ tanam (110 hari). Produksi perlakuan A mencapai $203,20 \mathrm{~kg}$ udang, B 411,60 kg udang + $160 \mathrm{~kg}$ beronang, C 290,20 kg udang + $192 \mathrm{~kg}$ beronang dan D $159 \mathrm{~kg}$ udang $+122 \mathrm{~kg}$ beronang/ha/musim tanam. Hasil analisis investasi menunjukkan bahwa hanya perlakuan B yang menguntungkan dengan Net Present Value (NPV) 18.384,58; Net Benefit/Cost (Net B/C) 3,21; dan Internal Rate of Return (IRR) 106,63\% yang disebabkan harga jual udang perlakuan B cukup tinggi yaitu Rp $21.000,00 / \mathrm{kg}$
\end{abstract}

\begin{abstract}
Investment analysis of the several stocking densities of rabbit fish, Siganus guttatus polycultured with tiger prawn, Penaeus monodon. By: Haseng Padda and Muhammad Tjaronge.

Polyculture of tiger prawn and rabbit fish is one of the alternative methods to increase production, productivity and farmer income. The purpose of this study was to identify the most profitable investment of tiger prawn and rabbit fish polyculture at different stocking densities. The experiment was arranged in a completely randomized design with four treatments with each three replications. Stocking density of treatment $A$ was 40,000 tiger prawn fry without any rab. bit fish and those of treatments $B, C$ and $D$ were 40,000 tiger prawn fry $+2,000 ; 4,000$ and 6,000 rabbit fish fry/ha/season (110 days), respectively. The productions per ha per season were A: tiger prawn $203.20 \mathrm{~kg}$; B: tiger prawn $411.60 \mathrm{~kg}+$ rabbit fish $160 \mathrm{~kg}$; C: tiger prawn $290.20 \mathrm{~kg}+$ rabbit fish $192 \mathrm{~kg}$ and D: tiger prawn $159 \mathrm{~kg}+$ rabbit fish $122 \mathrm{~kg}$. Investment analysis showed that treatment B was profitable with Net Present Value (NPV) 18,384.58; Net Benefit /Cost (Net/ C) 3.21; and Internal Rate of Return (IRR) $106.63 \%$. The high return in this treatment was due to high selling price of shrimp at treatment B which was $R p 21,000.00 / \mathrm{kg}$.
\end{abstract}

KEYWORDS: investment analysis, Siganus guttatus, Penaeus monodon, polyculture.

\section{PENDAHULUAN}

Polikultur udang windu dan beronang merupakan salah satu cara untuk meningkatkan produksi, produktivitas tambak dan pemanfaatan lingkungan secara optimal serta meningkatkan pendapatan petambak. Manfaat polikultur yaitu menjamin proses produksi dan memberikan nilai tambah melalui pemanfaatan relung ekologi (Suryana, 1987). Selanjutnya tambak merupakan satu diantara media untuk polikultur komoditas bernilai ekonomis tinggi termasuk antara lain beronang dan udang windu (Poernomo, 1986).

Kebiasaan beronang yang hidup berkelompok sangat menguntungkan bila dibudidayakan di tambak karena tidak memerlukan lahan yang luas. Udang windu hidup di dasar tambak sehingga kolom air di atasnya kurang dimanfaatkan secara efisien. Penambahan beronang yang diperkirakan dapat memanfaatkan relung ekologi yang belum dimanfaatkan udang windu diharapkan dapat meningkatkan produktivitas tambak.

Beronang memanfaatkan makanan alami berupa lumut di tambak yang tidak dimanfaatkan udang, sedangkan udang memanfaatkan detritus (jasad-jasad renik yang mati) sebagai makanan yang tidak dimanfaatkan oleh beronang. Polikultur nila merah dan beronang di keramba jaring apung ternyata cukup efektif untuk menanggulangi atau mencegah perkembangan biofouling termasuk lumut (Tonnek et al., 1993). Selanjutnya dikemukakan bahwa bobot kering biofouling pada monokultur nila merah $7.12 \mathrm{~g} / 10 \mathrm{~m}^{2} /$ bulan, sedangkan bobot kering pada polikultur nila merah dan

"Peneliti pada Balai Penelitian Perikanan Pantai, Maros 
beronang hanya $1.2 \mathrm{~g} / 10 \mathrm{~m}^{2} /$ bulan yang kebanyakan berupa partikel atau suspensi.

Penelitian ini bertujuan mengetahui investasi yang menguntungkan dari polikultur udang windu dan beronang pada beberapa kepadatan tebar.

\section{BAHAN DAN METODE}

Penelitian dilakukan di Instalasi Tambak Percobaan Balai Penelitian Budidaya Pantai Marana, Maros, Sulawesi Selatan pada bulan November 1993 s/d Februari 1994. Jumlah petakan yang digunakan 12 buah @ $500 \mathrm{~m}^{2}$. Penelitian menggunakan rancangan acak lengkap dengan empat perlakuan dan tiga ulangan. Ukuran benih beronang (Siganus guttatus) 21,6 g/ekor diperoleh dari nelayan di Kabupaten Takalar, sedangkan benur udang windu (Penaeus monodon) PL-17 diperoleh juga dari Kabupaten Takalar. Kepadatan tebar benih beronang perlakuan B, C dan D masing-masing $100,200,300$ ekor $/ 500 \mathrm{~m}^{2}$ atau $2000,4.000,6.000$ ekor/ha dan benur masing. masing 2.000 ekor $/ 500 \mathrm{~m}^{2}$ atau 40.000 ekor/ha/ musim tanam selama 110 hari. Sebagai kontrol adalah perlakuan $\mathrm{A}$ dengan kepadatan tebar benur 40.000 ekor/ha/musim tanam.

Persiapan tambak meliputi perbaikan pematang dan pintu air, pengolahan tanah dasar, pengeringan, pengapuran dengan dosis $1.000 \mathrm{~kg} /$ ha, pemberantasan hama menggunakan saponin dengan dosis $20 \mathrm{mg} / \mathrm{L}$ dan pemupukan digunakan urea dan TSP $=2: 1(\mathrm{~kg})$. Air dimasukkan secara bertahap sampai pakan alami tumbuh dengan normal kemudian dilakukan penebaran benur dan bibit beronang. Penebaran benur lebih awal 30 hari, maksudnya supaya masih ada kesempatan melakukan pemberantasan ikan liar dengan menggunakan saponin sebelum penebaran bibit beronang.

Dari hasil penelitian tersebut, maka penulis melakukan analisis investasi dari perlakuan yang menguntungkan, sebagai pegangan bagi yang berminat utamanya petambak dalam menginvestasikan modalnya pada sistem polikultur udang windu dan beronang.

Metode analisis investasi dilakukan dengan menghitung indikator berikut (Saleh, 1990):

$$
\text { Net Present Value }(N P V)=\text { Present Value }(\text { PV }) \text { Benefit }- \text { PV Cost }
$$
di mana:

- NPV adalah nilai bersih uang saat ini dari Benefit (Proceeds) dan Cost (Outlays).
- PV Benefit adalah nilai uang saat ini dari Benefit - PV Cost adalah nilai uang saat ini dari Cost

Bila NPV $>0$ berarti menguntungkan, sebaliknya, bila NPV < 0 berarti merugikan dan bila NPV $=0$, maka PV Benefit $=$ PV Cost.

Net Benefit $/$ Cost $($ Net $B / C)=\frac{P V \text { Net B yang positif }}{P V \text { Net B yang negatif }}$

di mana:

$$
=\frac{\operatorname{Net} B}{\operatorname{Net} C}
$$

- Net B/C adalah perbandingan Net B dengan Net C.

- PV Net Benefit $(\mathrm{B})$ yang positif $=\mathrm{PV}$ Net $\mathrm{B}>0$. - PV Net $B$ yang negatif $=$ PV Net $B<0$.

Bila Net $\mathrm{B} / \mathrm{C}>1$ berarti menguntungkan, sebaliknya bila Net $B / C<1$ merugikan dan Net $\mathrm{B} / \mathrm{C}=1$ maka PV Net B yang positif = PV Net B yang negatif atau Net $B=$ Net $C$.

Internal Rate of Return $=i *+\frac{N P V^{\prime \prime}}{N P V^{\prime \prime}-N P V^{\prime}}(i * *-i *)$

IRR adalah suatu tingkat bunga (Discount Rate) yang menunjukkan jumlah nilai sekarang/ nilai netto (NPV) sama dengan jumlah seluruh biaya investasi usaha.

NPV" (NPV positif) $=$ NPV $>0$

NPV' (NPV negatif) $=$ NPV $<0$

$\mathrm{i}^{*}=$ tingkat bunga yang berlaku (15\%).

$i^{\star *}=$ tingkat bunga yang memberi penerimaan nol atau negatif mendekati nol. Dalam hal ini tingkat bunga $108 \%$ memberi penerimaan negatif mendekati nol.

Bila IRR > tingkat bunga yang berlaku berarti menguntungkan, sebaliknya, bila IRR < tingkat bunga yang berlaku berarti merugikan. Bila IRR = tingkat bunga yang berlaku, maka tingkat pengembalian atas kapital yang belum selesai (masih diinvestasikan) hanya menutupi biaya modal (cost of capital).

\section{HASIL DAN PEMBAHASAN}

Hasil penelitian selama satu musim tanam (110 hari) memberikan produksi, laju sintasan, dan konversi pakan seperti yang tertera pada Tabel 1.

Produksi tinggi didapatkan pada perlakuan B, yaitu $20,58 \mathrm{~kg}$ udang $+8 \mathrm{~kg}$ beronang $/ 500 \mathrm{~m}^{2} /$ musim tanam atau $411,60 \mathrm{~kg}$ udang $+160 \mathrm{~kg}$ 
Tabel 1. Produksi, laju sintasan, konversi pakan per $500 \mathrm{~m}^{2}$ per musim tanam polikultur udang windu dan beronang untuk masing-masing perlakuan.

Table 1. Production, survival rate (SR) and food conversion ratio (FCR) per $500 \mathrm{~m}^{2}$ per season of each treatment in the polyculture of tiger prawn and rabbit fish*)

\begin{tabular}{|c|c|c|c|c|c|c|c|c|}
\hline \multirow[b]{2}{*}{$\begin{array}{l}\text { Perlakuan } \\
\text { Treatment }\end{array}$} & \multicolumn{2}{|c|}{$\begin{array}{l}\text { Udang windu } \\
\text { Tiger prawn }\end{array}$} & \multicolumn{6}{|c|}{ Beronang (Rabbit fish) } \\
\hline & $\begin{array}{c}\text { Ukuran } \\
\text { Size } \\
\text { (ind./kg) }\end{array}$ & $\begin{array}{c}\text { Produksi } \\
\text { Production } \\
\text { (kg) }\end{array}$ & $\begin{array}{l}\text { SR } \\
(\%) \\
\end{array}$ & FCR & $\begin{array}{c}\text { Ukuran } \\
\text { Size } \\
\text { (ind./kg) }\end{array}$ & $\begin{array}{c}\text { Produksi } \\
\text { Production } \\
\text { (kg) }\end{array}$ & $\begin{array}{l}\text { SR } \\
(\%)\end{array}$ & $\overline{\text { FCR }}$ \\
\hline A & 38 & 10.16 & 19.38 & 1.8 & - & - & - & - \\
\hline B & 32 & 20.58 & 33.28 & 2.1 & 8 & 8.0 & 67.0 & 3.1 \\
\hline $\mathrm{C}$ & 36 & 14.51 & 25.92 & 2.2 & 11 & 9.6 & 53.7 & 3.8 \\
\hline $\mathrm{D}$ & 38 & 7.95 & 15.20 & 2.3 & 28 & 6.1 & 56.4 & 3.0 \\
\hline
\end{tabular}

* Sumber (Source): Tjaronge et al., 1994

$\mathrm{A}=2.000$ benih udang windu (tiger prawn fry)/500 $\mathrm{m}^{2}$

$\mathrm{B}=2.000$ benih udang windu (tiger prawn fry) +100 beronang (rabbit fish fry)/500 $\mathrm{m}^{2}$

$\mathrm{C}=2.000$ benih udang windu (tiger prawn fry) +200 beronang (rabbit fish fry)/500 $\mathrm{m}^{2}$

$\mathrm{D}=2.000$ benih udang windu (tiger prawn fry) +300 beronang (rabbit fish fry) $/ 500 \mathrm{~m}^{2}$

beronang/ha/musim tanam, laju sintasan udang windu dan beronang masing-masing 33,28 dan $67 \%$, konversi pakan masing-masing 2,1 dan 3,10 . (Tabel 1). Perlakuan B yang paling menguntungkan disebabkan: laju sintasan udang windu paling tinggi $(33,28 \%)$ dibandingkan dengan laju sintasan perlakuan A, C dan D masing-masing hanya 19,$38 ; 25,92$ dan $15,20 \%$. Selain itu harga jual udang windu per kg perlakuan B paling tinggi karena ukuran udang dan bobot lebih besar $(31,25$ g/ekor) atau 32 ekor/kg dengan harga jual $\mathrm{Rp}$ $21.000,00 / \mathrm{kg}$ dibandingkan dengan perlakuan $\mathrm{A}$, dan D di mana ukuran udang per ekor lebih kecil (26,32 g/ekor) atau 38 ekor/kg dengan harga jual Rp 18.000,00/kg dan perlakuan C di mana bobot udang per ekor $27,78 \mathrm{~g}$ (36 ekor/kg) dengan harga jual Rp 19.000,00/kg; oleh karena semakin besar ukuran udang per ekor, maka semakin tinggi harga jualnya.

Adapun perbandingan hasil penelitian perlakuan B (Tjaronge et al., 1994) dengan penelitian terdahulu (Tjaronge et al., 1992 dan Burhanuddin \& Sulaeman, 1992) adalah sebagai berikut: Tjaronge et al. (1994) pada polikultur udang windu dan beronang, dengan kepadatan tebar masingmasing, benur 40.000 dan benih beronang 2.000 ekor/ha/ 110 hari memperoleh laju sintasan $33,28 \%$ (udang) dan 67\% (beronang). Rendahnya laju sintasan di sini diduga karena besarnya goncangan kadar garam yang bervariasi antara 6-35 ppt. Tjaronge et al. (1992) menyatakan bahwa dengan kepadatan tebar benur yang sama (40.000 ekor) tetapi benih beronang yang lebih rendah (1.500 ekor/ha/120 hari) memperoleh laju sintasan yang lebih tinggi untuk udang $(63,90 \%)$; tetapi lebih rendah untuk beronang yaitu $55,35 \%$. Burhanuddin \& Sulaeman (1992) pada monokultur beronang dengan kepadatan tebar benih 4.500 ekor/ha/120 hari memperoleh laju sintasan yang lebih tinggi $(87,30 \%)$.

Kegiatan polikultur udang windu dan beronang di tambak membutuhkan biaya variabel (VC) dan biaya tetap (FC). Biaya variabel dibayar sesuai dengan besarnya kegiatan usaha yang terdiri atas benih (benur+beronang), pakan, saponin, kapur, pupuk (urea+TSP), listrik, penggarap, transportasi, upah panen, dan lain-lain, sedangkan krei, saringan dan bambu dimasukkan sebagai biaya variabel karena dianggap hanya dapat digunakan dalam satu musim tanam tertera pada Tabel 2 . Selanjutnya besarnya beban biaya tetap yang harus dibayar walaupun tidak ada kegiatan usaha terdiri atas Pajak Bumi dan Bangunan (PBB), bunga bank dan penyusutan. Penyusutan dihitung secara garis lurus atau nilainya sama setiap tahunnya sesuai umur ekonomis barang modal investasi (Castle et al., 1987) tertera pada Tabel 3.

Adapun kebutuhan modal polikultur udang windu dan beronang per ha dari perlakuan $\mathrm{A}, \mathrm{B}, \mathrm{C}$ dan $\mathrm{D}$ terdiri atas modal investasi masing- masing sebesar $83,78 \%$; $75,72 \% ; 76,86 \%$; dan $80,55 \%$ dan modal kerja masing-masing sebesar $16,22 \%$; $24,28 \% ; 23,14 \%$ dan $19,45 \%$. Modal investasi 


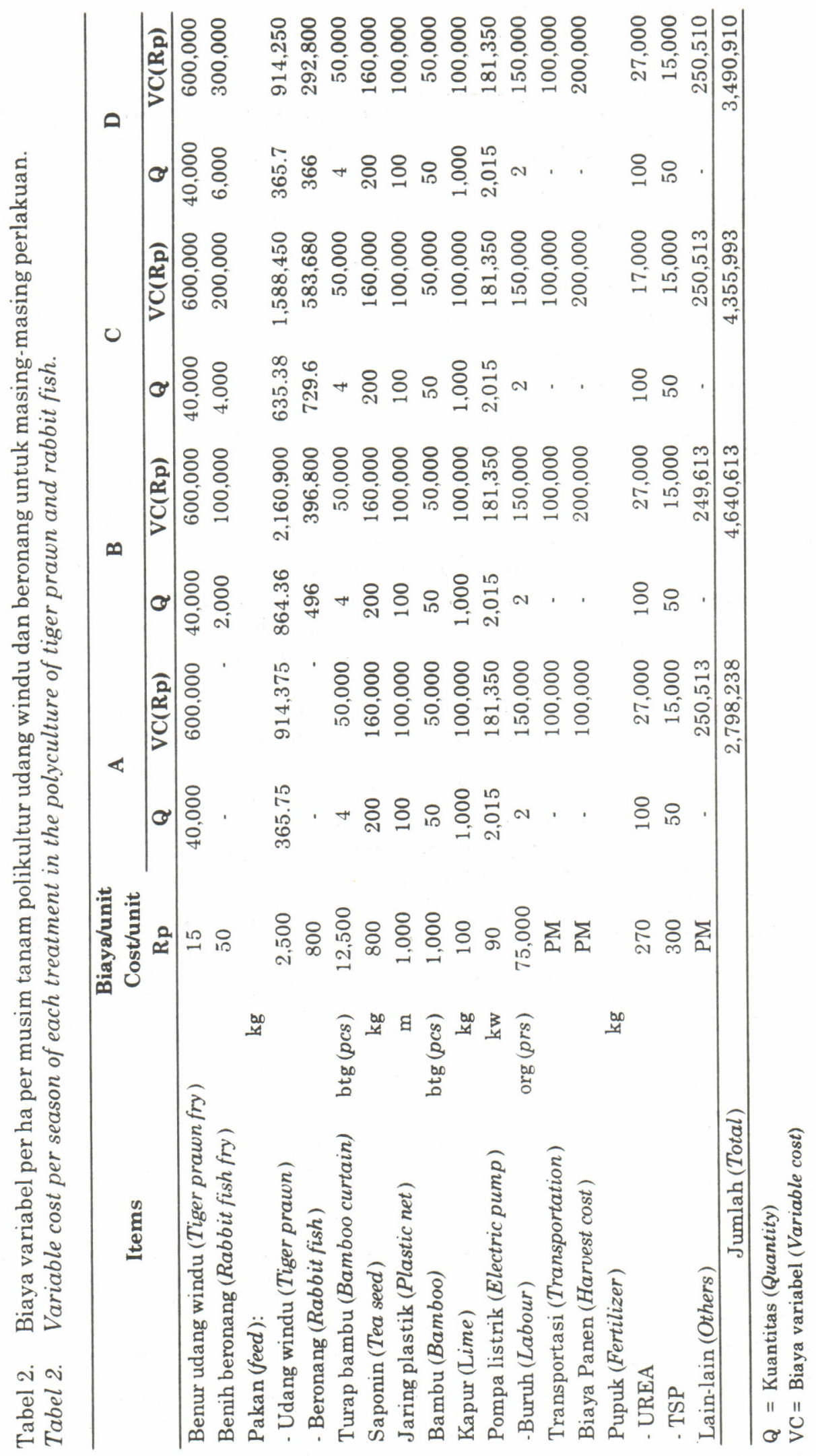


Tabel 3. Biaya tetap per ha per musim tanam polikultur udang windu dan beronang untuk masing-masing perlakuan.

Table 3. Fixed cost per ha per season of each treatment in the polyculture of tiger prawn and rabbit fish.

\begin{tabular}{llrrr}
\hline \multirow{2}{*}{ No. $\begin{array}{c}\text { Biaya tetap } \\
\text { Fixed cost }\end{array}$} & \multicolumn{4}{c}{ Perlakuan (Treatment) (Rp 000) } \\
\cline { 2 - 5 } & \multicolumn{1}{c}{ A } & \multicolumn{1}{c}{ B } & C & D \\
\hline A. Penyusutan (Depreciation) & & & & \\
1. Sewa lahan (Pond lease) & 250.00 & 250.00 & 250.00 & 250.00 \\
2. Konstruksi (Construction) & 200.00 & 200.00 & 200.00 & 200.00 \\
3. Pompa air (Water pump) (10") & 450.00 & 450.00 & 450.00 & 450.00 \\
4. Instalasi listrik (Electric Installation) & 400.00 & 400.00 & 400.00 & 400.00 \\
(16.5 kw) & & & & \\
5. Rumah jaga (Guard house) & 100.00 & 100.00 & 100.00 & 100.00 \\
B. Bunga (Interest) 15\% & $1,087.50$ & $1,087.50$ & 1.087 .50 & $1,087.50$ \\
C. Pajak Bumi dan Bangunan (Tax Land) & 10.00 & 10.00 & 10.00 & 10.00 \\
\hline
\end{tabular}

diasumsikan berasal dari bank dengan tingkat bunga $15 \%$ per tahun dan modal kerja ditanggung petambak dengan tingkat bunga yang sama tertera pada Tabel 4 .

Dalam polikultur udang windu dan beronang, harga input yang mengalami kenaikan dari tahun ke tahun menyebabkan biaya variabel input naik sekitar 5\%/tahun yang diikuti kenaikan nilai penjualan juga sekitar $5 \% /$ tahun dan selanjutnya dilakukan perhitungan rugi dan laba. Perhitungan rugi dan laba polikultur udang windu dan beronang dengan asumsi dua musim tanam (pemeliharaan) per tahun diproyeksikan selama lima tahun sebab investor pada umumnya akan menginvestasikan modalnya selama lima tahun (Padda \& Mangampa,

Tabel 4. Kebutuhan modal investasi dan modal kerja polikultur udang windu dan beronang per ha untuk masing-masing perlakuan.

Table 4. Required investment capital and working capital per ha of each treatment in polyculture of tiger prawn and rabbit fish.

\begin{tabular}{|c|c|c|c|c|c|c|}
\hline \multirow{2}{*}{\multicolumn{2}{|c|}{ Jenis modal (Kind of capital) }} & \multirow{2}{*}{ Unit } & \multicolumn{4}{|c|}{ Perlakuan (Treatment) $(\mathrm{Rp} 000)$} \\
\hline & & & $\mathbf{A}$ & B & C & D \\
\hline \multicolumn{7}{|l|}{ I. Modal Investasi (Investment) } \\
\hline $\begin{array}{l}\text { 1. Sewa lahan } 5 \text { tahun } \\
\text { Pond lease ( } 5 \text { year) }\end{array}$ & ha & 1 & $2,500.00$ & $2,500.00$ & $2,500.00$ & $2,500.00$ \\
\hline $\begin{array}{l}\text { 2. Konstruksi ( } 5 \text { tahun) } \\
\text { Construction ( } 5 \text { year) }\end{array}$ & ha & 1 & $2,000.00$ & $2,000.00$ & $2,000.00$ & $2,000.00$ \\
\hline 3. Rumah jaga (Guard house) & unit $(p c s)$ & 1 & $2,000.00$ & $2,000.00$ & $2,000.00$ & $2,000.00$ \\
\hline 4. Pompa air (Water pump) & unit $(p c s)$ & 1 & $4,500.00$ & $4,500.00$ & $4,500.00$ & $4,500.00$ \\
\hline $\begin{array}{l}\text { 5. Instalasi listrik (Electric } \\
\text { installation) }\end{array}$ & $16.5 \mathrm{kw}$ & PM & $4,000.00$ & $4,000.00$ & $4,000.00$ & $4,000.00$ \\
\hline Subtotal I & & & $14,500.00$ & $14,500.00$ & $14,500.00$ & $14,500.00$ \\
\hline \multicolumn{7}{|l|}{ II. Modal berjalan (Working capital) } \\
\hline 1. Biaya variabel (Variable cost) & & & $2,798.238$ & $4,640.663$ & $4,355.993$ & $3,490.913$ \\
\hline 2. Biaya kas (Cash cost) & & & 10.00 & 10.00 & 10.00 & 10.00 \\
\hline Subtotal II & & & $2,808.238$ & $4,650.663$ & 4365.993 & $3,500.913$ \\
\hline Total I + II & & & $17,308.238$ & $19,150.663$ & $18,865.993$ & $18,000.913$ \\
\hline
\end{tabular}


1993). Dengan waktu tersebut biasanya modal investasi sudah bisa kembali dan sudah memper. oleh keuntungan.

Dari hasil perhitungan rugi dan laba ternyata hanya perlakuan $B$ yang menguntungkan yaitu tahun I Rp 4.610.870,00; tahun II Rp 5.091.160,00; tahun III Rp 5.595.470,00; tahun IV 6.125.000,00 dan tahun V Rp 6.681.000,00; sedangkan perlakuan $A$ dan $D$ mengalami kerugian selama lima tahun dan perlakuan $\mathrm{C}$ baru untung pada tahun $\mathrm{V}$ sebesar Rp 153.400,00 sehingga tidak dilanjutkan analisisnya seperti tertera pada Tabel 5 .

Perhitungan Present Value dari Cost dan Benefit perlakuan B disajikan berdasarkan cash flow yakni aliran kas masuk (in flow) dan keluar (out flow) untuk mengetahui Net Cash Flow (aliran kas bersih) tertera pada Tabel 6. Sedangkan NPV dari Cost (outlays) dan Benefit (proceeds) dari Net Cash Flow perlakuan B tertera pada Tabel 7.

Dari Tabel 7 dapat dihitung:

1. NPV positif (NPV pada tingkat bunga $15 \%)=$ $35.036,08-16.651,50=18.384,58$.

NPV negatif (NPV pada tingkat bunga 108\%) $=8.931,86-9.207,64=-275,78$.
2. Net $\mathrm{B} / \mathrm{C}=\left(\mathrm{B}^{\prime \prime} \cdot \mathrm{C}\right) /\left(\mathrm{B}^{\prime}-\mathrm{C}\right)=3,21$

3. $\operatorname{IRR}=15 \%+(108 \%-15 \%)=106,0.63 \%$

Hasil analisis investasi menunjukkan bahwa hanya perlakuan $B$ yang menguntungkan (kepadatan tebar 40.000 ekor benur +2.000 ekor benih beronang/ha/musim tanam) karena NPV positif (18.384,58); Net B/C 3,21 (>1); dan IRR $106,63 \%$ (jauh lebih besar dari tingkat bunga yang berlaku sebesar $15 \%)$. Hal ini merupakan daya tarik petambak dan investor yang akan menanam dan memperluas usahanya. Sejalan pendapat Gittinger (1982), analisis investasi usaha tani dimaksudkan untuk menentukan daya tarik suatu usaha investasi terhadap petani dan pihak lain termasuk masyarakat secara keseluruhan.

Menurut Pasaribu (1995) teknologi budidaya udang windu yang menguntungkan di Jawa Timur adalah semi intensif dengan Net B/C 1,1 dan IRR $21,74 \%$ dengan benefit (nilai penjualan naik $10 \%$ per tahun). Temuan tersebut memperkuat pernyataan bahwa teknologi ekstensif polikultur udang windu dan beronang pada perlakuan $B$ jauh lebih menguntungkan karena Net $\mathrm{B} / \mathrm{C}=3,21(>1,1)$ dan IRR 106,63\% (>21,74\%) dengan biaya variabel dan nilai penjualan naik $5 \%$ per tahun.

Tabel 5. Perhitungan ruga laba polikultur udang windu dan beronang untuk masing-masing perlakuan selama 5 tahun.

Table 5. Profit and loss of each treatment in the polyculture of tiger prawn and rabbit fish for 5 years.

\begin{tabular}{|c|c|c|c|c|c|c|}
\hline \multirow{2}{*}{$\begin{array}{l}\text { Perlakuan } \\
\text { Treatment }\end{array}$} & \multirow{2}{*}{$\begin{array}{c}\text { Rugi/laba } \\
\text { Loss/profit }\end{array}$} & \multicolumn{5}{|c|}{ Tahun (Year) (Rp 000) } \\
\hline & & $\mathbf{I}$ & II & IV & IV & $\mathbf{v}$ \\
\hline A & Rugi (Loss) & $3,276.28$ & $3,190.34$ & $3,100.12$ & $3,005.30$ & $3,905.90$ \\
\hline B & Laba bersih (Net profit) & $4,610.87$ & $5,091.16$ & $5,595.47$ & $6,125.00$ & $6,681.00$ \\
\hline $\mathrm{C}$ & Rugi (Loss) & 759.39 & 547.16 & 325.24 & 91.76 & $153.40^{\star}$ \\
\hline D & Rugi (Loss) & $5,032.83$ & $5,034.72$ & $5,038.71$ & $5,038.79$ & $5,040.98$ \\
\hline
\end{tabular}

* Laba pada perlakuan C didapat pada tahun ke-5 sebesar Rp 153.400, (Profit in treatment $C$ is obtained in year Vabout $R p$ 153,400,-)

Harga pasar udang windu (Market price of tiger prawn) (1994) 1 US $\$=R p 2.197,00$

$\mathrm{B}=32$ Ind. $/ \mathrm{kg} \mathrm{Rp} 21,000.00$

$\mathrm{C}=36$ Ind $. / \mathrm{kg} \mathrm{Rp} 19,000.00$

$\mathrm{A}, \mathrm{D}=38 \mathrm{Ind} . / \mathrm{kg} \mathrm{Rp} 18,000.00$

Beronang (Rabbit fish)/kg Rp 5,000.00 
Tabel 6. Proyeksi cash flow tiap perlakuan selama lima tahun polikultur udang windu 13.171 ekor $(411,60 \mathrm{~kg})$ dan beronang 1.280 ekor $(160 \mathrm{~kg})$.

Table 6. Projection of cash flow for 5 year of each treatment in the polyculture of tiger prawn 13,171 tails $(411.60 \mathrm{~kg})$ and rabbit fish 1,280 tails $(160 \mathrm{~kg})$.

\begin{tabular}{|c|c|c|c|c|c|}
\hline $\begin{array}{l}\text { Items (Year) } \\
\text { (Rp 000) }\end{array}$ & I & II & II & IV & V \\
\hline \multicolumn{6}{|l|}{$\begin{array}{l}\text { Aliran kas masuk (In flow): } \\
\text { Revenue }\end{array}$} \\
\hline 1 Udang windu (Tiger prawn) & 17.287 .20 & $18,151.56$ & $19,059.14$ & $20,012.10$ & $21,012.71$ \\
\hline 2 Beronang (Rabbit fish) & $1,600.00$ & $1,680.00$ & $1,764.00$ & $1,952.20$ & $1,944.81$ \\
\hline $\begin{array}{l}\text { B. Total aliran kas masuk } \\
\text { (Total in flow) (A) }\end{array}$ & $18,887.20$ & $19,831.56$ & $20,823.14$ & $21,864.30$ & $22,957.52$ \\
\hline \multicolumn{6}{|l|}{ C. Aliran kas keluar (Out flow): } \\
\hline $\begin{array}{l}1 \text { Masukan biaya variabel } \\
\text { Variable cost input }\end{array}$ & $9,281.33$ & $9,745.40$ & $10,232.67$ & $10,744.30$ & $11,281.52$ \\
\hline $\begin{array}{l}2 \text { Pajak Bumi dan Bangunan } \\
\text { Land and building tax }\end{array}$ & 20.00 & 20.00 & 20.00 & 20.00 & 20.00 \\
\hline \multirow{2}{*}{$\begin{array}{l}\text { D. Total aliran kas kelua } \\
\text { (Total out flow (B) } \\
\text { Net Cash Flow (A-B) }\end{array}$} & $9,301.33$ & $9,765.40$ & $10,252.67$ & $10,764.30$ & $11,301.52$ \\
\hline & $9,585.87$ & $10,066.16$ & $10,570.47$ & $11,100.00$ & $11,656.00$ \\
\hline
\end{tabular}

Tabel 7. Net Present Value dari cost dan benefit perlakuan B polikultur udang windu 13.171 ekor $(411,60 \mathrm{~kg})$ dan beronang 1.280 ekor $(160 \mathrm{~kg})$ selama 5 tahun.

Table 7. Net Present Value of outlays and benefit of treatment $B$ in the polyculture of tiger prawn 13,171 tails $(411.60 \mathrm{~kg})$ and rabbit fish 1,280 tails $(160 \mathrm{~kg})$ of 5 years.

\begin{tabular}{|c|c|c|c|c|c|c|c|c|c|c|}
\hline \multirow{2}{*}{$\begin{array}{l}\text { Thn } \\
\text { Year }\end{array}$} & \multirow{2}{*}{ Outlays } & \multirow{2}{*}{ Proceeds } & \multirow{2}{*}{$\begin{array}{c}\text { DF } \\
15 \%\end{array}$} & \multicolumn{4}{|c|}{ Present Value } & \multirow{2}{*}{$\begin{array}{c}\text { DF } \\
108 \%\end{array}$} & \multicolumn{2}{|c|}{ Present Value } \\
\hline & & & & C & B & $\mathbf{B}^{\prime}-\mathrm{C}^{\prime}$ & B"-C & & $\mathbf{C}$ & B \\
\hline I & 19.150 .66 & $9,585.87$ & 0.8695 & $16,651.50$ & $8,316.91$ & $8,316.59$ & $\cdot$ & 0.4808 & $9,207.64$ & $4,608.89$ \\
\hline II & & $10,066.16$ & 0.7561 & $\cdot$ & $7,611.02$ & - & $7,611.02$ & 0.2311 & $\cdot$ & $2,326.29$ \\
\hline III & . & $10,570.47$ & 0.6575 & - & $6,950.08$ & $\cdot$ & $6,950.08$ & 0.1111 & - & $1,174.38$ \\
\hline IV & - & $11,100.00$ & 0.5717 & $\cdot$ & $6,345.87$ & - & $6,345.87$ & 0.0534 & - & 592.74 \\
\hline $\mathrm{V}$ & . & $11,656.00$ & 0.4971 & . & $5,794.20$ & - & $5,794.20$ & 0.0257 & . & 229.56 \\
\hline & $19,150.66$ & $52,978.50$ & & $16,651.50$ & $35,036.08$ & $8,316.59$ & $26,701.17$ & & $9,207.64$ & $8,931.86$ \\
\hline $\begin{array}{l}\text { C } \\
\text { B } \\
B^{\prime} \cdot C \\
B^{\prime \prime} \cdot C \\
\text { DF }\end{array}$ & $\begin{array}{l}=\text { Cost } \\
=\text { Benefit } \\
=\text { Negativ } \\
=\text { Positive } \\
=\text { Discoun }\end{array}$ & $\begin{array}{l}\text { e Benefit } \\
\text { e Benefit } \\
\text { Factor }\end{array}$ & & & & & & & & \\
\hline
\end{tabular}




\section{KESIMPULAN}

Berdasarkan hasil analisis investasi lima tahun pertama ternyata bahwa hanya perlakuan B (benur 40.000 ekor dan benih beronang 2.000 ekor) yang paling menguntungkan dengan produksi $411,60 \mathrm{~kg}$ udang dan $160 \mathrm{~kg}$ beronang/ ha/musim tanam; laju sintasan masing-masing 33,28 dan $67 \%$ dan konversi pakan masing-masing 2,1 dan 3,1. Perlakuan B menguntungkan karena NPV positif (18.384,58); Net B/C > $1(3,21)$; dan IRR 106,63\% (lebih besar dari tingkat bunga yang berlaku sebesar $15 \%$ ).

\section{DAFTAR PUSTAKA}

Burhanuddin dan Sulaeman. 1992. Pengaruh padat penebaran terhadap pertumbuhan ikan beronang Siganus javus di tambak. Jurnal Penelitian Budidaya Pantai. 8(2): 81-86.

Castle, E., M. H. Backer dan A. G. Nelson. 1987. Farm Business Management. Macmillan Publishing Co., Division of Macmillan, Inc., U.S.A. 413pp.

Gittinger, J. P. 1982. Economic Analysis of Agricultural Project. The John Hopkins University Press, U.S.A. $505 \mathrm{pp}$.

Pasaribu, A. M. 1995. Efisiensi Ekonomi, Alokasi Sumber Daya dan Investasi dalam Pengembangan Teknologi Budidaya Udang Windu (Penaeus monodon) di Jawa Timur. Disertasi untuk memperoleh Gelar Doktor dalam Ilmu Pertanian pada Universitas Negeri Padjadjaran, Bandung. 194 hal.
Padda, H. dan M. Mangampa. 1993. Analisis ekonomi percobaan penggantian air dan lama aerasi dalam budidaya udang windu secara intensif di tambak Marana, Kabupaten Maros, Sulawesi Selatan. Prosiding Seminar Hasil Penelitian Perikanan Pantai, Maros. No. 11: 161.168.

Poernomo, A. 1986. Tambak atau mangrove. Badan Penelitian dan Pengembangan Pertanian Jakarta. Panel Diskusi Daya Guna dan Batas Lebar Jalur Hijau Hutan Mangrove. 27 Februari - 1 Maret 1986, Ciloto. Kontribusi Badan Penelitian dan Pengembangan Pertanian. 19 hal.

Suryana, A. 1987. Pengembangan komoditas ekspor hasil pertanian dengan pendekatan diversifikasi usaha. Jurnal Penelitian dan Pengembangan Pertanian. 6 (1): 18.21.

Saleh. A. K. 1990. Perencanaan dan Evaluasi Proyek KUD. Lembaga Penelitian Univ. Hasanuddin. Ujung Pandang. 34 hal.

Tjaronge M., M. Mangampa, A.G Mangawe dan A. Ismail. 1992. Polikultur udang windu. Penaeus monodon dan ikan beronang. Siganus sp. secara semiintensif di tambak. Jurnal Penelitian Budidaya Pantai. 8 (2) 81.86.

Tjaronge, M., A.G Mangawe dan M. Mangampa 1994. Perbedaan padat penebaran beronang lada, Siganus guttatus dalam polikultur dengan udang windu, Penaeus monodon. Jurnal Penelitian Budidaya Pantai. Maros. 10 (2): 79.

Tonnek, S., D.S. Pongsapan dan Rachmansyah. 1993. Polikultur nila merah dan beronang dalam keramba jaring apung di laut. Jurnal Penelitian Budidaya Pantai, 9 (3): 47.54. 